\title{
How to Deal with Muslims? Raymond Lull and Ignatius of Loyola
}

\author{
Paul Richard Blum
}

As a small contribution to the topic of the relationship between Christians and Muslims, I should like to exploit two sources that shed light on it from a late medieval and a Renaissance angle. ${ }^{1}$ One is Raymond Lull's Vita coetanea ${ }^{2}$ and the other is Ignatius of Loyola's autobiography, which was originally referred to as Acta P. Ignatii. ${ }^{3}$ What is peculiar about these sources is that both are non-thematic accounts of the relation of a Christian to Muslims; each is an autobiographical narrative about events that occurred before the author's main career, but which was dictated late in his life. In addition, the narratives are indubitably designed to instruct their followers, as they are written in the third person, which decreases subjectivity and enhances authority. I tend to read the two accounts as deliberate messages about what was important to each author, to the effect that all of Acta may be read as an agenda et vitanda because the narrated facts acquire emblematic meaning. If we keep in mind Ignatius's instruction to visualize the life of Christ (compositio loci), we may as well visualize the episodes of his life for the sake of gaining delight and instruction about our own courses of action. Without further ado, here is a quick summary of the two stories:

1 The title of this article has been deemed provocative by some people. The word 'to deal with' appeared to be demeaning. However, there must have been a suspicion that this 'dealing' might be derogatory because it is about Muslims. Honi soit qui mal y pense. And indeed, both Ignatius and Lull did not think highly of Muslims. Therefore, I want to share the way both converted in their views, in addition to the conclusions we may draw.

2 Raimundus Lullus, Vita coetanea, n. 189, in Raimundi Lullii Opera Latina, ed. Hermogenes Harada, vol. 8, Corpus Christianorum Continuatio Medievalis, 34 (Turnholti: Brepols, 1980), 261-309. English quotations are taken from Anthony Bonner, ed., 'Doctor illuminatus'. A Ramon Llull Reader (Princeton: Princeton University Press, 1993).

3 Acta S. Ignatii in Scripta de Sancto Ignatio de Loyola, vol. 1, Monumenta Ignatiana, series quarta (Matriti: Lopez del Horno, 1901), 31-98 (Spanish). English quotations, cited as Reminiscences, are taken from Ignatius of Loyola, Personal Writings, ed. Joseph A. Munitz and Philip Endean (London: Penguin, 2004); on the production of the autobiography see Introduction, 8-11. 
Raymond Lull's (1232-1315) narrative has to do with his Saracen slave who had taught him Arabic. One day in 1273, he and his slave began to fight after the slave uttered some anti-Christian slurs. While the Saracen was in prison, Lull was tormented by the thought that he might be obliged to kill his teacherservant. When the prisoner had hanged himself, Lull thanked God for sparing him from having to soil his hands. Ignatius of Loyola's account, on the other hand, occurred in 1522, when he encountered a Moor who ridiculed the virginity of St. Mary. Unsure about whether or not to go after him, Ignatius let his mule decide. As a result, he saw it to be God's will to proceed to Montserrat, instead of fighting the Muslim.

In both cases, it is not the wickedness or ignorance of the Muslims that drives the conflict; instead, it is the weakness of the Christians. Let us now take a closer look into the biographical and theoretical contexts of each story, in order to see whether there is a pattern that helps in conceptualizing the Christian-Muslim relationships.

\section{Raymond and the Slave}

There is no need to explain further the structure and origin of the Vita coetanea $;{ }^{4}$ however, what is worth stressing is the fact that it is a narrative of conversion and illumination. ${ }^{5}$ In this narrative construction, the slave episode is located after Raymond had completed a peregrination and had accepted that he would return home instead of going to Paris. When he arrived at home, he tells us, he did three things: he dressed himself in the simplest fashion, he learned Latin (here rather than in Paris), and, "having bought himself a Saracen,

4 Cf. Vita coetanea, 261-263; Erhard Wolfram Platzeck, Raimund Lull. Sein Leben-Seine Werke, Die Grundlagen seines Denkens, 2 vols (Düsseldorf: Schwann, 1962-1964) vol. 2, p. 66*; idem, Das Leben des seligen Raimund Lull. Die 'Vita coetanea' und ausgewählte Texte (Düsseldorf: Patmos, 1964), 21-26. Jordi Gayà, “'De conversione sua ad poenitentiam' Reflexiones ante la edición crítica de Vita Coetanea," Estudios Lulianos 24 (1980): 87-91. Anita Obermeier, The History and Anatomy of Auctorial Self-Criticism in the European Middle Ages (Amsterdam: Rodopi, 1999), 229-231 (nothing on the slave episode). Cf. Domínguez and Gayà, "Life," in Raimundus Lullus. An Introduction to his Life, Works and Thought, ed. Alexander Fidora and Josep E. Rubio, Corpus Christianorum Continuatio Medevalis 214; Raimundi Lullii Opera Latina 2 (Turnhout: Brepols, 2008), 3-124; on the Vita $5^{-8 .}$

5 Mark D. Johnston, “Ramon Llull's Conversion to Penitence," Mystics Quarterly 16/4 (1990): 179-192. 
he learned the Arabic language from him." ${ }^{\prime 6}$ From this, we gather that his role as a hermit and his study of Latin and Arabic are one act.

After that, there follows a lacuna of nine years: "Nine years later, it happened that... his Saracen slave blasphemed the name of Christ." ${ }^{7}$ This gap in time is famous because filling it would provide details about Raymond's education. From the narrative point of view, it is pointless to speculate what he might have been doing during those nine years. In fact, what matters is that Lull refuses to tell us. The plot says: the upshot of nine years of retirement and study was that the slave spoke up against his master. Since the episode ends with the death of the slave, one may even interpret this gap as the effective obliteration of the content of the nine years of formation. ${ }^{8}$

The exact blasphemy regarding the name of Christ is unclear. As an indication, however, one may turn to the narrative in the manuscript Breviculum, which has the merit of giving a historically close interpretation. In this account, the Saracen says: "Christ is fake, because he preached to be God and deified man, and incarnate." ${ }^{9}$ Here is not the place to contemplate the probability that the slave may have uttered something to this effect, because it would require a historical discussion of the Muslim interpretation of Christ. To grasp the implications of the narrative, it is more interesting to look instead at Lull's Christology. His teaching on Christ emphasizes humility. For instance, the

6 Vita coetanea, $\mathrm{n}$. 11 ; Bonner, Doctor illuminatus, 15 . On slaves and Moors in Mallorca at Lull's times, see Domínguez and Gayà, "Life", passim. The question of symbolism in this phase of Lull's life has been raised in Fernando Domínguez Reboiras, "Idea y estructura de la Vita Raymundi Lulii," Estudios Lulianos 27 (1987): 1-20, 12-13.

7 Bonner, Doctor illuminatus, 16.

8 Amador Vega, Ramon Llull and the Secret of Life (New York: Crossroad, 2002), 7. Another possibility is that the elderly Lull, in affirming his authority, wanted to blur over heterodox sources he had studied: Massimo Candellero, "Un importante documento biografico lulliano: la Vita coetanea," Istituto Univeristario Orientale Annali, sezione romana 34/1 (1992) [Atti del Convegno Internazionale Ramon Llull, il lullismo internazionale, l'Italia]: 15-33, $28 \mathrm{f}$.

9 Ramon Llull, Breviculum seu Electorium parvum Thomae Migerii (Le Myésier), ed. Charles Lohr, Theodor Pindl-Büchel and Walburga Büchel, Corpus Christianorum, Continuatio Mediaevalis. Raimundi Lulli Opera Latina. Supplementum Lullianum, 1 (Turnhout: Brepols, 1990), 283-8, 311-356. Here I take advantage of the online edition http://lullianarts.net/ miniatures/mini/BREVo3.HTM, retrieved April 1, 2014, table 3: "Numquid vides, Raimundus, in hoc Alcorano, quod cum scias legere, intelligere et loqui arabicum, quod pulchrius dictamen nec aequale in pulchritudine homo nec angelus possent facere, a quo igitur factum est a Deo solo, et ex quo ergo a Macometo nobis traditus est? Numquid Dei nuntius et propheta dici potest et exaudiri a Deo, cum pro nobis Deum rogaverit in die iudicii? Falsum Christum, qui praedicavit se Deum hominem deificatum, incarnatum, qui dixit Deum tantum et trinum et unum esse?" (my translation). 
Liber contemplationis subsumes Christ's humility under humility as a divine attribute:

Praise and glory and blessing to Your sacred humility; for in the same measure as it is great and admirable through the fact that You willed to descend from the highest good and highness into this world to take on flesh, so the magnitude of haughtiness in us wants to elevate us to the dignities and heights and honors to which we are not entitled. ${ }^{10}$

The Saracen's allegation stands in stark contrast with the theological interpretation of what is known as kenosis, which according to Lull is inversely proportionate to man's arrogance. Elsewhere, Lull emphasizes that God became incarnate not for the sake of human redemption, as often expected, but rather for the sake of self-revelation and consequent love. ${ }^{11}$ This is a theology based on divine dignity and hierarchical imbalance. ${ }^{12}$ Lull suggests remedying exaggerated pride by contemplating God's humble descent into human flesh. In fact, in the following chapter, Lull relates haughtiness to irascibility: "As haughtiness makes humans irascible, boorish, and ill-behaved, so Your [Christ's] humility made man amiable, simple, and well-behaved while You were in this world among humans."13 With due fairness, in his Book of the Gentile, Lull has the Saracen interlocutor claim the same divine humility for the Prophet Mohammed, which has been bestowed upon him by God in order to prevent

10 Raimundus Lullus, Liber magnus contemplationis in Deum, tomus 3 (Palma de Mallorca: Cerdà, Antich, Amoròs, 1746), vol. 1, l. 2, dist. 19, cap. 87, n. 13, p. 211: "Tuae sanctae Humilitati sit laus et goria et benedictio; quia, sicut ipsa est magna et mirabilis per hoc, quod voluerit (!) de supremis bonis et altitudinibus Te descendere in hunc mundum ad assumendum Carnem; ita magnitudo superbiae, quae est in nobis, vult nos elevare ad nobilitates et ad altitudines et ad honores ad nos non pertinentes." In Catalan: Ramon Llull, Libre de Contemplació en Deu, ed. Antoni M.a Alcover and Mateu Obrador i Bennássar, vol. 2 (Palma de Mallorca: Comissió Editora Lulliana, 1906), (Obres de Ramon LLull, vol. 3; reprint Palma: Miquel Font, 1989), 152.

11 Tomás and Joaquin Carrèras y Artau, Historia de la filosofia española. Filosofia cristiana de los siglos XIII al XV, vol. 1 (Madrid: Real Academia de ciencias exactas físicas y naturales, 1939), 505-507. Cf. Carles Llinàs Puente, "Angelología y Cristología en Ramon Llull," Studia Lulliana 48 (2008): 41-68; 56-64.

Details in Walter Andreas Euler, Unitas et Pax. Religionsvergleich bei Raimundus Lullus und Nikolaus von Kues, 2nd. ed. (Würzburg-Altenberge: Echter/Oros, 1995), 84-92.

13 Liber Contemplationis, ibid., cap. 88, n. 27, p. 225: "Sicut superbia facit hominem iracundum et rusticum et male morigeratum, ita Humilitas Te fecit esse hominem dulcem et simplicem et suavem et bene morigeratum, quando eras in mundo hominum." Libre de Contemplació, 159. 
pride and vainglory. ${ }^{14}$ These two sources were composed around the time of the event with the Saracen; later, we see Lull accusing infidels (Jews in this case) of using the name of God 'in vain,' that is, as an accidental description rather than invoking His theological essence. Here, the blasphemy consists of understanding the name of God in human terms. ${ }^{15}$ In his later Disputation with Hamar the Saracen (1308), written a few years before dictating his reminiscences, Lull has the Muslim contrast the absolute attributes of God with the finitude that is entailed in the incarnation. ${ }^{16}$ Lull, the narrator, certainly does not suggest that his slave-teacher had such sophisticated arguments at hand, but he does return to the subject of strife. In the conclusion to the disputation, he notes that the book made use exclusively of "rational arguments rather than authorities, for authorities become acrimonious through conflicting interpretations." ${ }^{17}$ Exaggeration, pride, haughtiness, and concomitant ire surround his Christology, and that is precisely what follows in the autobiographical narrative.

Following the aforementioned incident, Raymond loses his temper (nimio zelo motus) and beats the slave. ${ }^{18}$ The slave, however, resisted — but what made him resist? He grew enraged to the same extent that Raymond had exceeded what was appropriate: "As a result, the Saracen became extremely embittered (rancore nimio inde concepto), and he began plotting against his master."19

14 Lullus, The Book of the Gentile and the Three Wise Men, book 4, n. 3, in Bonner, Doctor illuminatus, 144.

15 Ramón Lull, El “Liber predicationis contra Judeos," ed. José M.a Millás Vallicrosa (MadridBarcelona: Istituto Arias Montano, 1957), de 9.o sermone, p. 87: "Idcirco infideles nomen Dei accipiunt in vanum, eo quia blasphemunt nomina Dei intrinseca, scilicet deitantem, deitatum et deitare. Item infideles accipiunt nomen Dei... quo ad descriptionem, sicut homo qui magis perfecte nominat alium hominem diffiniendo ipsum quam describendo..."

16 Raimundus Lullus, Disputatio Raymundi Christiani et Hamar Saraceni, in Opera, vol. 4 (Mainz: Mayer, 1729) (separate pagination), 2-12. On the specific theology of this work see Hans Daiber, "Raimundus Lullus in der Auseinandersetzung mit dem Islam. Eine philosophiegeschichtliche Analyse des Liber disputationis Raimundi Christiani et Homeri Saraceni," in Juden, Christen, und Muslime. Religionsdialoge im Mittelalter, ed. Matthias Lutz-Bachmann and Alexander Fidora (Darmstadt: Wissenschaftliche Buchgesellschaft, 2004), 136-172; on the Saracen's, view 138-148.

17 Disputatio, 46: “... ut Christianus et Saracenus per Rationes, non per Autoritates, ad invicem disputarent; nam Authoritates calumniantur ratione diversarum expositionum." This does not at all mean that Lull would desist from accusing Muslims from converting Christians, as Lull continues.

18 Vita coetanea, n. 11; Bonner, Doctor illuminatus, $16 \mathrm{f}$.

19 Vita coetanea, n. 11; Bonner, Doctor illuminatus, 17. Peers, following the later Catalan version, has: "Now the said slave was of a very haughty spirit, and further... he had a great 
Charles de Bovelles (1479-1567) broadened this analysis by narrating that the "purchased Saracen feared that Raymond's education might become dangerous for the Mohammedan religion (particularly because he had exacted to be trained in speaking Arabic only for the purpose of preaching). ${ }^{20}$ While this may be true, Raymond focuses on the equivalence of passions. The question evoked is not about the intentions of the Muslim or the would-be missionary, but the pent-up zeal on both sides.

Consequently, the slave plotted to kill his master. While shouting "You're dead!" he managed to get hold of a sword, with which he attacked and wounded his master. But Raymond overcame the attacker. ${ }^{21}$ While the athletic Franciscan friar Erhard Wolfram Platzeck relished the prowess and strength of his hero, ${ }^{22}$ it appears to be more important that Lull, after so many adventures, still reminds his readers that he had been wounded and that physical violence was needed to stop the assault. Whereas the philosopher emerges from the event physically victorious, he finds himself in a spiritual and moral standoff. Having prevented his household from killing the Muslim, and having locked him up, he subsequently faced a dilemma: ${ }^{23}$ to put him to death would have been severe and harsh, since the culprit was his Arabic teacher, after all; however, to release him appeared too dangerous. Obviously, the dilemma comes from the very same relationship that had led to the fight, namely, that the slave-owner was subordinate to the slave as a teacher, or in other words, the Christian had made himself dependent on the Muslim for the sake of subduing him (or any other version that describes this imbalanced relationship).

If we look at Lull's predicament as a paradigm of a global pattern, we may say: one conundrum encountered in the attitude of the Christian world towards the Muslim world is that any assertion of hegemony depends upon the ability to understand the allegedly lower religion; however, any effort to understand the other religion creates a kind of coexistence in which using violence would be contradictory. This mutual dependency appears to be the result of the most elementary attempt at living with the target of the mission.

wrath at these blows..." (E. Allison Peers, Ramon Lull. A Biography (London: Society for Promoting Christian Knowledge, 1920), 41).

20 Carolus Bovillus, Vita, in Acta Sanctorum, Junii tomus septimus (Paris-Rome: Palme, 1867), June 30, 613-618; n. 5, cap. 2, p. 616A: "Timensque ideo emptitius Saracenus, qui eum docuerat, ne Raemundi doctrina Mahumenticae legi perniciosa fieret (praesertim cum solius praedicationis causa, Arabici sermonis peritia, ab eo se imbui postulasset)..."

21 Vita coetanea, n. 12; Bonner, Doctor illuminatus, 17.

22 Platzeck, Das Leben des seligen Raimund Lull, 152: "Die Szene zeigt uns einen körperlich noch gewandten Raimund, der dazu über beachtliche Kräfte verfügte."

23 This has been carefully analyzed in M. V. Dougherty, Moral Dilemmas in Medieval Thought. From Gratian to Aquinas (Cambridge: University Press, 2011), 94-101. 
In terms of slave-master relationship, we see that the mutual instruction (language traded for Christian education) brings the slave-teacher to hate the master's religion, whereas the master-student is prevented from bluntly exercising his power. Since this leads the slave to take recourse to verbal abuse, the master then falls into violence, which only induces the slave to attempt taking the master's life. At this point, the master gains the upper hand not only by overwhelming the attacker, but, more importantly, by putting an end to the violence. Now, let us see how the story ends.

In his 'perplexity,' Raymond retires to praying to God. In a classic mystical pattern, he is 'sad' about God's persistent silence. Upon returning home, he made a detour to the prison cell in order to see after the captive, and found that his slave had hanged himself with the very "rope with which he had been bound." 24 Obviously, the poor man had no other tool for his suicide, a reader might flippantly remark. Why should Lull remember this detail after forty years? In a symbolic reading, the Muslim was put to death by his Christian host, and yet he agreed to it and participated actively in his defeat. In this sense, he took the weapon out of his master's hand (as the master had extorted the sword from his own hand) and executed himself. We moderns would, of course, expect that upon seeing this, Lull would mourn the loss of his teacher of Arabic. Instead, we learn that Lull "joyfully gave thanks to God, not only for keeping his hands innocent (innoxias) of the death of this Saracen but also for freeing him from that terrible perplexity concerning which he had just recently so anxiously asked Him for guidance."25

According to Michael Dougherty, it is a pattern of the Vita coetanea that Lull ascribes, or even imputes, the solution of moral dilemmas to divine intervention. ${ }^{26}$ In fact, this is consistent with the mystical persona that emerges from the Vita. The solution is external to his actions, and yet, it resolves his conflicting intentions: the blasphemer and attacker is dead without having soiled the missionary's hands.

The next step in the narrative is the divine inspiration of the Ars major. In a symbolic reading, post haec is propter haec. ${ }^{27}$ After retiring for nine years to study Latin and Arabic, the Muslim teacher becomes a threat that is removed by divine intervention, thus clearing the way for the intuition of the new

24 Vita coetanea, n. 13: "inuenit, quod ipse fune, quo ligatus fuit, iugulauerat semet ipsum"; Bonner, Doctor illuminatus, 17.

25 Ibid.

26 Dougherty, Dilemmas, 101.

27 Vita coetanea, n. 14, p. 280: "Post haec Raimundus ascendit in montem quendam..." 
method to convert Muslims with rational arguments. What are we then supposed to learn from this narrative?

- Mission inevitably requires acculturation, that is, immersion in the culture of those who are the intended subjects of conversion.

- Familiarity with the world of the others, however, tends to become mutual: the inherent negation of the culture to be converted will be turned against the missionaries and their haughty behavior. The slave sees through the ruse of the master and consequently emulates him.

- The 'sword' of the sermon therefore tends to fall back into the sword of violence, which is an instantaneous and mutual twist.

- Hence, there follows a predicament of violence and non-violence that cannot be resolved but by external intervention.

- Does this not tell us, regarding mission to non-believers: do not even try?

As we all know, Lull kept trying and advocating — continuously and with endurance-for the usage of both swords. ${ }^{28}$ The Breviculum underscores this through its use of military imagery, even when illustrating Aristotelian and Lullian logic. ${ }^{29}$ Also, to give up mission would indeed end the dialectics of acquaintance and hostility that is at the heart of our episode. One might even argue that the contention in verbal disputations carries out this very dialectic. In the same way as only God could have it both ways, namely, leaving Lull innocent and yet having the attacker killed, it is also God who commands him to try both swords, and not only the militant one. In this dialectical reading, the most troubling sub-dilemma is the death of the Saracen, if we identify him as both the target of mission (manifest in his role as a slave) and the facilitator of the acculturation attempt by Lull (manifest in his role as the teacher). Why must the teacher die? The answer may lie in two details: first, that Raymond did not regret his teacher's death, and second, that Raymond quotes his teacher's threatening remark: "You are dead!" The first point indicates that this is not a novel about sensibilities, but about the dilemmatic structure of mission as such. The second, moreover, says that the religion to be converted must 'die,' or in other words, disappear from the tribulations of the missionary, and only

28 Cf. Paul Richard Blum, Philosophy of Religion in the Renaissance (Farnham: Ashgate, 2010), 1-14, on Lull's advocating the two swords in the sense of conversion by the word and by crusade.

29 See Breviculum, images 6 and 7. 
then is the mission accomplished. ${ }^{30}$ In historical reality, Lull repeatedly travelled to Northern Africa, where he engaged in disputes with Islamic authorities. Eventually, he was attacked and driven out. Despite this, the divine command remains: maintain your innocence! Whether it is possible to remain innocent while subjugating another culture is a question that Lull patently answers in the affirmative. Thus, Lull's way of speaking about God to Muslims is totally independent of the Holy Scripture because it is purely logical; consequently, he hoped his new logic would be apt to convince Muslims of the truth of Christianity, and that is what he kept doing for the rest of his long life. His paradoxical way to teach Christian revelation was based on his personal revelation that there might be a transcultural method of communication, namely, his Lullian art.

\section{Ignatius and the Moor}

Let us now switch to Ignatius of Loyola's encounter with a Moor. ${ }^{31}$ This event happened in 1522, about two hundred and fifty years after Lull. As I previously mentioned, the narrative structure of his account is the same as Lull's: Ignatius is telling, in third person, the story of his own life to a confidant. ${ }^{32}$ Furthermore, both events occur at similar points in each author's life: the saint is also approaching his spiritual and intellectual breakthrough. In the narrative, Ignatius is on his way to Montserrat to pay homage to the Black Madonna. It is here that he inserts the episode of when he met a Moor. The epithet 'moor' may have been derogatory at that time, ${ }^{33}$ and if so, it was probably intentional because the thrust of the narrative argument is to desist from persecution, as

$30 \quad$ A symbolic interpretation, ventured in Johnston, "Conversion to Penitence," 184, would be: "Ignorant of Divine Truth, they [the Averroist and Muslim audiences] will inevitably destroy themselves and, like suicides, incur eternal damnation." Among the irenic interpretations championing inter-cultural exchange I may mention Berthold Altaner, "Glaubenszwang und Glaubensfreiheit in der Missionstheorie des Raymundus Lullus. Ein Beitrag zur Geschichte des Tolleranzgedankens," Historisches Jahrbuch 47 (1928): 586-610, 591 .

31 For the socio-cultural context, see Marjorie O'Rourke Boyle, Loyola's Acts. The Rhetoric of the Self (Berkeley: University of California Press, 1997), 6o-65. The status of the debate about Saint Mary's virginity in Islamic sources is beyond the scope of my study.

That the words recorded are his is obvious from Louis Gonçalves da Câmara, the secretary who received the dictation and describes in detail Ignatius's design and determination. See Munitz and Endean, "Introduction," in Personal Writings, 4-7. 
we will see. Moreover, already fifty years later when Pedro Ribadeneira (15271611) wrote the first biography of the founder of the Society of Jesus in 1572, he felt the need to explain that there actually lived "Saracens or Moors" in Aragon as remainders of that "ancient tribe." ${ }^{34}$ Daniello Bartoli (1608-1685) also uses the term 'Moresco' in his very popular biography from 1650 , and adds that this person was a Muslim. ${ }^{35}$ From this we are reminded that, from the narrative standpoint of the later Ignatius, the Moor had to be a Muslim for the story to be plausible. ${ }^{36}$

Ignatius emphasizes that it is worthwhile for the episode "to have [been] written, so that people can understand how our Lord used to deal with this soul." This is because the not so young but newly converted man is on his way to Montserrat; however, his soul at the time "was still blind, though with great desires to serve [God] as far as its knowledge went." ${ }^{37}$ And so, with youthful vanity, he dreams of great 'exploits' (hazañas) in the footsteps of the great saints, unaware that his dreams were nothing but 'exterior deeds' devoid of humility and patience, not to mention discernment. ${ }^{38}$ It cannot escape the intended readership that Ignatius is inserting key terms regarding his spirituality. Even after the Moor incident that he is about to recount, Ignatius entertains chivalric fantasies, modeled on the knight errant Amadis that would later be parodied by Cervantes. We shall return to the motif of chivalry. At this point,

34 Petrus Ribadeneira, Vita Ingatii Loiolae...(Matriti: Gomezius, 1586), cap. 3, fol. 8r: "Sarracenus quidam sive Maurus", and he explains: "Erant per id tempus in Hispania Tarraconensi adhuc aliqui ex antiquis eius gentis reliquiis." Cf. Pedro Leturia, Iñigo de Loyola, trans. Aloysius J. Owen (Syracuse: Le Moyne College Press, 1949), 137 f.

35 Daniello Bartoli, Della vita e dell'istituto di S. Ignatio ... libri cinque (Roma: Manelfi, 1650), lib. 1, cap. 9, p. 25: "Un viandante, di stirpe Moresco, e di Religione Maomettano, de quali, in que' tempi era gran numero ne' Regni di Valenza, e d'Aragona..." From these testimonies that are closer to the events than modern interpretations we may gather that, if there was any negative ring in the autobiography, then the early Jesuits clarified the terminology and the historical facts.

36 Boyle, Acts, 61 surmises that at that time the 'moor' must have been a Morisco, i.e. baptized. However, that does not play out in the narrative.

37 Ignatius, Reminiscences, n. 14, p. 18. Acta S. Ignatii, p. 44.: “... será bueno escriuirse, para que se entienda cómo nuestro Señor se abía con esta ánima, que aun estaua ciega, avunque con grandes deseos de servirle en todo lo que conociese..."

38 Ignatius, Reminiscences, n. 14, p. 18-19; "exploits" n. 17, p. 20 (Acta, p. 46). Acta, p. 45: “... no mirando á cosa ninguna interiror, ni sabiendo qué cosa era humildad, ni charidad, ni patiencia, ni discretion..., sino toda su intención era hazer destas obras grandes exteriores..." 
though, we may assume that the irony of Ignatius following the knightly path on a mule may have been narrated on purpose. ${ }^{39}$

During the journey, Ignatius encounters another traveler on a mule, a Moor. The two of them begin conversing about Our Lady. In their exchange, the Muslim accepts the virginity in conception but doubts the possibility that Mary remained a virgin after giving birth, invoking 'natural reasons.' We do not learn what kind of response Ignatius had to offer. ${ }^{40}$ We only see that he loses the argument, which is depicted in the narrative with the image that he lost sight of the speeding Moor. The reported detail that this fellow traveler appealed to natural reasons may have suggested to readers that the Moor was a physician and was therefore capable of arguing as a naturalist. At any rate, the Moor must have been well versed in Christian doctrine.

It is well known that the virginity of Our Lady can only be defended by theological or mystical arguments. A mystical argument has been imputed to Ignatius by the dramatist Pedro Calderón de la Barca (1600-1681).41 Thomas Aquinas, moreover, had adduced a series of theological arguments, based on the dignity of the Mother for the sake of the dignity of the son, Christ. ${ }^{42}$ The Jesuit Francisco Suárez (1548-1617) will later comment on this article and ascribe the blasphemy - specifically that Mary could not remain a virgin after giving birth - to Protestant heretics (not to Muslims), singling out Erasmus of Rotterdam. His discussion of the question regarding her virginity post partum alone extends over four folio pages and invokes a great number of Church Fathers and scholastic authorities, which shows that the Muslim's objection was not at all outrageous. ${ }^{43}$ Jacobus Pontanus (1542-1626), the Jesuit professor in Augsburg, however, poked fun of the issue in the 1580s. In one of his school comedies, the main character Stratocles ridicules classic education by scolding the muse "Lady Calliope, allegedly a virgin (a 'virgin' who gave birth to both

39 Mules were not appropriate for gentlemen, see Boyle, Acts, $53 \mathrm{f}$.

40 Also Ribadeneira has "naturales rationes aliquot" without saying how Ignatius responded (Vita, 8r). Bartoli makes the Moor appear "empio" and arguing "perfidiosamente," to which Ignatius responded "con similitudini, e con ragioni" (Della vita, 26), thus blaming the Moor.

Pedro Calderón de la Barca, El gran Príncipe de Fez Don Baltasar de Loyola, jornada II, esc. 16 compares the birth of Christ with sunlight passing through glass; excerpts in Leturia, Iñigo, $177 \mathrm{f}$.

43 Franciscus Suárez, Commentariorum et disputationum in tertiam partem divi Thomae tomus secundus (Venetiis: Apud Minimam Societatem, 1594), q. 28, art. 1-3, disp. 5, sect. 2, $75^{-78 .}$ 
Linus and Rhesus)." ${ }^{44}$ We may conclude from these parallels that the goal of the narrative was not to expose the content of the blasphemy, but the change of attitude in Ignatius.

Given the careful choice of words in Ignatius's seemingly simple narrative, it may be significant that the narrator refers to himself as 'the pilgrim' at this point, since it is not the charisma of a pilgrim to engage in theological and scientific debates. At any rate, following the incident, he becomes enraged and feels "obliged to stand up for [St. Mary's] honor" and to stab the blasphemer. ${ }^{45}$ Instead of praying explicitly, the Pilgrim follows a pattern familiar to him from his beloved chivalric novels: since the Moor was continuing for a while on their common route but soon would turn off the shared road, Ignatius decided not to decide himself, but let the mule go on a loose rein and choose whichever path it would take. ${ }^{46}$ Ignatius reports that God willed to have his mule choose the path that would spare the Muslim's life. ${ }^{47}$ After this incident, Ignatius proceeded to Montserrat.

With this course of action, the author is employing a chivalric plot device that would have been very familiar to his audience. For instance, Amadis, in the anonymous novel with this same title, had a dream in which his horse, with loosened reins, would carry him out of troubles. ${ }^{48}$ And early in his career as a knight, Don Quixote comes to a crossroads and, undecided where to go and explicitly imitating the knights-errant, lets the horse decide (which then chooses to return home) ${ }^{49}$ Although I have no evidence that Ignatius was aware of it, it is worth mentioning that Raymond Lull, in his book on the Order of the Knights, also discusses the symbolism of the reins, rendering it the following way:

44 Jacobus Pontanus, Soldier or Scholar. Stratocles or War, ed. Thomas D. McCreight and Paul Richard Blum (Baltimore: Apprentice House, 2009), lines 46 f.: "Domina Calliope, quam esse narrant virginem / (Si virgo est, quae Linumque, Rhesumque peperit).” Translation from this bilingual edition; cf. comment, $133 \mathrm{f}$.

45 Ignatius, Reminiscences, n. 15, 19.

46 Acta, n. 16, p. 46: “... no hallando cosa cierta á que se determinasse, se determine en esto, scilicet, de dexar yr la mula con la rienda suelta...”

47 Ignatius, Reminiscences n. 16, p. 19.

48 Vasco Lobeira, Amadis of Gaul, vol. 1 (London: Smith, 1872), book 2, chapter 3, 266.

49 Miguel de Cervantes, El ingenioso hidalgo don Quijote de la Mancha, [1605], I 4; read at http://www.gutenberg.org/files/2000/200o-h/2000-h.htm\#1_iv. Leturia, Iñigo, 140, note 6o, mentions Don Quijote. 
A bridle is put on the horse, and into the hands of the knight the reins are given. This signifies that with the bridle the knight shall bridle his mouth from speaking evil or false words, that he shall bridle his hands not to give so much as to need to beg thereafter, nor shall he be so reckless that his courage becomes mindless. And through the reins he should understand that he shall let himself be guided wherever the Order of the Knights wants to engage or send him. And whenever necessary [...] he should be courageous and not fear his enemies, and if he hesitates to injure them, make it vanish from valor. And if he does the contrary of that, then his horse, which is a beast without reason, will follow the rule and duty of knighthood better than the knight. ${ }^{50}$

This advice is unmistakably Lullian, as it pairs rationality with trust in divine authority. Ignatius adopts a similar attitude that leaves emotional response behind while trusting the wisdom of the beast.

In a more direct way than Lull, Ignatius finds himself in a dilemma, namely, to murder the Muslim or to let him go. Ignatius's biographer, Daniello Bartoli, outlines the dilemma in a way similar to what we saw with Lull: outrage and zeal inflamed Ignatius, who already perceived himself as a 'Cavaliere di Christo', which brought him into 'doubt and perplexity' as he heard an 'inner spirit' saying that punishment is public whereas private revenge does not befit a Christian. As a result, "he left the judgment to Chance, or-as he thought—-to Heaven." Eventually, it was God's compassion (pietà) for the inexpert novice, still unable to tell the duties of a Christian from the impulses (spiriti) of a knight, which willed that the horse (cavallo, not mule) take the other way. "Hence Ignatius concluded it to be God's will that [the Moor] lived or at least he should not kill him."51

5o Raimondo Lullo, Libro dell'Ordine della Cavalleria [Libre qui és de l'Ordre de Cavalleria], ed. Giovanni Allegra. ([Carmagnola]: Arktos, 1994), part 5, sect. 14, 206: "A cavall és donat fre, e a les mans del cavaller són donades regnes, a significança que cavaller pe lo fre refrèn sa boca de parlar letges paraules e falses; e refrèn ses mans que no dó tant que haja a quérrer, ni sia tan ardit que de son ardiment git seny. E per les regnes entena que ell se leix menar vers qual part l'ordre de cavalleria lo vulla aempar ni trametre. E con hi serà mester, [...] e que sia ardit, e no dubte sos enemics; e con dubtarà de ferir, leix flaquea de coratge. E si d'açò lo cavaller fa lo contrari, son cavall, qui és bèstia que no ha raó, segueix mills la regla e l'ofici de cavalleria que lo cavaller."

$5^{1}$ Bartoli, Della vita, lib. 1, p. 26, the episode concludes with the words: “... d'onde Ignatio interpretò, esser voler di Dio, o che colui vivesse, o almeno ch'egli non l'uccidesse." This sentence is missing in the English translation: Daniel Bartoli, History of the Life and 
We know that throughout his years of pilgrimage, Ignatius always wanted to go to Jerusalem. In fact, he planned to go there right after his visit to the Black Madonna of Montserrat. Eventually, after many frustrations and disappointments, while his still unofficial Society never managed to get a passage to the Holy Land, he desisted from his plans only because Christ himself appeared to him at La Storta, saying: "In Rome I will be more favorable to you." ${ }^{2}$ The choice of the mule in our episode has the same message as Christ on the way to Rome: divert your itinerary away from your mission to the Muslims and towards what later would be called the Catholic Reformation!

In terms of ideology and personal mindset, the universal message of Ignatius's narrative may actually lie in the chivalric framework. Pierre Quesnel (1699-1774), an eighteenth-century French biographer, enhanced exactly those motives and called Ignatius a 'Chevalier de la Vierge' in the title of his book, which bears a title plate with the Saint holding vigil in front of the Madonna. ${ }^{53}$ While following closely the autobiography and Bartoli's biography, ${ }^{54}$ he points out that Ignatius compared the mundane and the spiritual versions of knighthood, opting for the latter, though still with 'marvelous things' in his head. ${ }^{55}$ This interpretation agrees with that of Ribadeneira, who surmises that Ignatius at that juncture was still too much of a soldier and held on to fallacious ideals

Institute of St. Ignatius de Loyola ..., trans. Author of "Life in Mexico," vol. 1 (New York: Dunigan, 1855), 42.

$52 \quad$ Acta, n. 96.

53 [Pierre Quesnel], Histoire de l'admirable Dom Inigo de Guipuscoa, Chevalier de la Vierge, et fondateur de la Monarchie des Inighistes... Par le Sieur Hercule Rasiel de Selva, vol. 1 (La Haye: Charles le Vier, 1736). This book has been reprinted a few times. According to Dr. Hoefer, Nouvelle biographie générale, vol. 41 (Paris: Didot, 1862), col. 323 f., Quesnel is also author of an anonymous critical Histoire Des Religieux De La Compagnie De Jesus... Pour servir de Suplément a l'Histoire Ecclésiastique des XVI, XVII \& XVIII siécles, in four vols. (Soleure: Librairies Associés, 1740), which also narrates Ignatius' life, however in a very different tone. There is more on Quesnel as a journalist in Lynn Hunt, Margaret C. Jacob, and Wijnand Mijnhardt, The Book that Changed Europe. Picart and Bernard's "Religious Ceremonies of the World" (Cambridge, Mass.: Harvard University Press, 2010), 336 n. 22. Thanks to Ugo Baldini for ascertaining in the Jesuit archives that Quesnel was not affiliated with the Jesuits.

54 Quesnel's book presents itself as a chivalric novel, suppressing the name Loyola, but de facto it is a biography.

55 Quesnel, n. XIII, 16: “... après avoir comparé la Chevalerie errante Mondaine avec la Spirituelle, donna la Préférence à celle-ci, parce qu'il y trouva un plus grand Merveilleux.” 
of honor. ${ }^{56}$ Quesnel further explains that Ignatius followed the model of Amadis and other 'Histoires Romanesques,' which requires that new knights hold a 'vigil in armes' before being accepted into the order. ${ }^{57}$ In his view, Ignatius wanted to fulfill this 'essential formality,' and therefore held the vigil described in the autobiography. This is how he became a Knight of the Virgin. ${ }^{58}$ Shortly thereafter, Quesnel continues, the unknown knight would make the hitherto unknown town of Manresa 'extrémement célèbre,' thanks to the Pilgrim's 'penitence.' Although he adopted this observation from Bartoli's account, ${ }^{59}$ he added that in this Ignatius surpassed "Amadis de Gaule... et...Dom Quichotte." ${ }^{60}$ Even though we are aware that in reality it was Cervantes who imitated Ignatius and his role models, this remark does not necessarily abate the piety of the Saint, but rather ridicules-in agreement with the Pilgrim - the exterior orientation that remains ostentatious in its modesty. An English translation of the book has even promoted Ignatius to a 'Spiritual Quixote.' ${ }^{61}$ With this, however, the author and the translator clearly take advantage of the Pilgrim's self-critique, especially the critique of the chivalric ideology and pride that kept besetting him. We should remember that Ignatius dictates his memoir late in his life when he was critical of his chivalric beginnings, and that he is showing how slowly he freed himself from them.

From this perspective, the vigil at Montserrat may acquire an important meaning for our interpretation of the Moor episode. For Ignatius does not immediately hold this vigil; rather, in the order that he tells it, he first ponders the examples of "Amadis of Gaul and books of that sort" and chooses "to abandon his clothes and to clothe himself in the armour of Christ."

$5^{6}$ Ribadeneira, Vita, cap. 3, fol. 8v: "Homo quippe militaris, et fallaci veri honoris imitatione olim delusus..."

57 Similarly, Bartoli, Della vita, 28. On this and other rules concerning the chivalric vigil, see Leturia, Iñigo, 141-144. On such vigils in honor of St. Mary, required from new to be invested knights in the Middle Ages, see Léon Gautier, La chevalerie (Paris: Welter, 1895), 288-291, which included depositing weapons on the altar. Also Lull reports the vigil in arms: Libro dell'Ordine della Cavalleria, part 4, sect. 3, 180-182 and note 4.

$5^{8}$ Quesnel, n. XVI, 25 f. Cf. Acta/Reminiscences, n. 17-18. Cf. Bartoli, Della vita, 28, and Ribadeneira, Vita, cap. 4, p. 9 v.

59 Bartoli, Della vita, cap. 11, p. 29: "E Manresa ... famosa hoggidì, e venerabile per le memorie che conserva ... dell'estreme penitenze, che S. Ignatio vi fece."

6o Quesnel, n. XVIII, 27 .

61 [Pierre Quesnel], The Spiritual Quixote; Or, the Entertaining History of Don Ignatius Loyola, Founder of the Order of the Jesuits.... (London: Bouquet, 1755). The French text (p. 3) says at the beginning that Ignatius made himself "aussi fameux dans la Chevalerie errante Spirituelle, que Dom Quichotte, son illustre Compatriote, l'a été dans la Mondaine.” 
Following this, he delivers a general confession to his confessor, and with the same confessor he arranges to take the mule and to hang his sword and dagger in the church "at the altar of Our Lady." Ignatius emphasizes that this was an important decision. ${ }^{62}$ Then, he enacts his plans and abdicates all attributes of violence by dressing as a mendicant and pilgrim, and by holding the vigil "with his staff in his hands," i.e., as a pilgrim. So, the French biographer was correct: Ignatius does change the worldly knighthood into a spiritual one, and by giving his weapons as $e x$ voto $^{63}$ to St. Mary, he begins transforming courtship into Marian devotion. ${ }^{64}$ While conducting the ritual of initiation into knighthood, Ignatius sheds the mundane knighthood and becomes a vassal of Christ. From now on persecuting Muslims is no longer an objective, the founder of the Jesuits ultimately exhorts his readers.

Compared with Lull's experience and message, Ignatius's is simpler; however, it also simplifies and reduces the problem. For in his narrative, the drive to the Holy Land and to convert Muslims appears to be a mere impulse, the naïve calling of a descendant of the knightly class. He describes it as the same impulse to imitate the saints: 65 mere daydreams of a youth who has not yet realized that the role of a hero and the role of a companion of Jesus are conflicting and incompatible. God and the mule must determine the true calling. ${ }^{66}$

It is understandable now that the Moor episode foretells the La Storta vision, which was held to be the key to the Jesuits' mission away from the Muslims and towards reform within the Christian world (which was almost torn apart by

62 Ignatius, Reminiscences, n. 17, 20; Acta, 47 uses the term “determinación”. [See p. 171, with note 46]

63 James Broderick, Saint Ignatius Loyola. The Pilgrim Years (New York: Farrar, Straus and Cudhay, 1956), 85. Bartoli, Della vita, lib. 1, cap. 10, 28 has Ignatius leave dagger and sword only after the night and assigns the act no specific importance.

64 I am indebted to Robert Miola for prompting me to investigate this motif.

65 Acta, nn. 7, 9, 14, 24.

66 Andrew Olesh, Jr., suggests comparing both narratives with the experience of St. Francis of Assisi. Indeed, the Fioretti tell an episode that is comparable, namely, when Francis converts the Sultan. See Guido Davico Bonino, ed., I fioretti di San Francesco (Milan: Einaudi, 1964), chapter 24, 66-68. The components of predication and God's intervention are there; however, it is not the saint who refrains from violence but the Muslim; and it is (most likely) not a firsthand dictated narrative. John Victor Tolan, Saint Francis and the Sultan: The Curious History of a Christian-Muslim Encounter (Oxford: Oxford University Press, 2009) is a study of the episode in the medieval context and its reception through the centuries. 
heretics of all brands). Therefore, compared with Lull's narrative, the CounterReformation narrative teaches:

- Mission in the post-medieval world requires rational discourse.

- The other knows at least as much about the would-be missionary as the missionary does about the other. Hence, a civil discourse is necessary but possibly without result.

- The sword of the sermon has turned into the sword of persuasion, and where that fails, even violence is pointless.

- If the missionary is ignorant of the dialectics of violence and non-violence, he should take recourse to external intervention.

- Consequently, regarding mission to non-believers: do not even try! Reform your own religious behavior instead.

These are the conclusions we may draw from Ignatius's narrative. When compared with the conclusions drawn from Lull's narrative, they mark a clear development following the realization of the paradoxical or even dialectical nature of converting others, which eventually led towards the internal reform of Christianity as it took place during the sixteenth century. 